University of Nebraska - Lincoln

DigitalCommons@University of Nebraska - Lincoln

Faculty Publications from the Harold W. Manter Laboratory of Parasitology

1971

\title{
Observations on Parasite-Host Relationships of Echinococcus multilocularis Leuckart, 1863, in North Dakota
}

Robert L. Rausch

Arctic health Research Center, rausch@u.washington.edu

S. H. Richards

North Dakota Game and Fish Department

Follow this and additional works at: https://digitalcommons.unl.edu/parasitologyfacpubs

Part of the Parasitology Commons

Rausch, Robert L. and Richards, S. H., "Observations on Parasite-Host Relationships of Echinococcus multilocularis Leuckart, 1863, in North Dakota" (1971). Faculty Publications from the Harold W. Manter Laboratory of Parasitology. 610.

https://digitalcommons.unl.edu/parasitologyfacpubs/610

This Article is brought to you for free and open access by the Parasitology, Harold W. Manter Laboratory of at DigitalCommons@University of Nebraska - Lincoln. It has been accepted for inclusion in Faculty Publications from the Harold W. Manter Laboratory of Parasitology by an authorized administrator of DigitalCommons@University of Nebraska - Lincoln. 


\title{
Observations on parasite-host relationships of Echinococcus multilocularis Leuckart, 1863, in North Dakota
}

\author{
R. L. RAUSCH AND S. H. RICHARDS ${ }^{1}$ \\ Arctic Health Research Center, \\ U.S. Department of Health, Education, and Welfare, College, Alaska, \\ and \\ North Dakota Game and Fish Department, Jamestown, North Dakota \\ Received May 10, 1971
}

\begin{abstract}
RaUSCH, R. L., and S. H. Richards. 1971. Observations on parasite-host relationships of Echinococcus multilocularis Leuckart, 1863, in North Dakota. Can. J. Zool. 49: 1317-1330.

Red foxes, Vulpes vulpes (Linnaeus), and small mammals were collected and examined during 1965-69, to investigate parasite-host relationships of Echinococcus multilocularis Leuckart, 1863, in North Dakota. Comparative studies of this cestode were carried on concurrently through experimental infection of carnivores and rodents. In winter, red foxes in North Dakota exhibited high rates of infection of comparatively low intensity. Deer mice, Peromyscus maniculatus (Wagner), and voles, Microtus pennsylvanicus (Ord), were important intermediate hosts, but the larvae in deer mice produced fewer protoscolices. The strains of E. multilocularis from North Dakota and from St. Lawrence Island, Alaska, differ biologically, as indicated by findings in experimentally infected rodents, but they could not be distinguished morphologically at the infraspecific level. Helminths recorded from red foxes in North Dakota are listed, and some ecological data are presented and discussed.
\end{abstract}

Des renards Vulpes vulpes (Linnée) et d'autres petits mammifères du Dakota du Nord ont été capturés et examinés au cours des années 1965 à 1969 en vue d'établir les relations parasites-hôtes avec Echinococcus multilocularis Leuckart, 1863. Des expériences d'infestation de carnivores et de rongeurs ont été menées simultanément pour faire des études comparées sur ce cestode. En hiver, les renards du Dakota du Nord présentent un haut degré d'infestation. La souris Peromyscus maniculatus (Wagner) et le mulot Microtus pennsylvanicus (Ord) sont d'importants hôtes intermédiaires, mais chez la souris, les larves produisent peu de protoscolex. La lignée d' $E$. multilocularis du Dakota du Nord diffère biologiquement de celle de St. Lawrence Island (Alaska) d'après les résultats obtenus avec l'infestation expérimentale des rongeurs, mais ces deux lignées ne présentent pas de différences morphologiques justifiant la création de sous-espèces. On donne aussi une liste des helminthes trouvés chez les renards du Dakota du Nord, ainsi que des données écologiques qui sont discutées.

In 1965 , following the report by Leiby and Olsen (1964) of the occurrence of Echinococcus multilocularis Leuckart, 1863, in North Dakota, a cooperative study between the North Dakota Game and Fish Department and the Zoonotic Disease Section of the Arctic Health Research Center was begun, to investigate the distribution and parasite-host relationships of the cestode in this region. An attempt was first made to collect mammals of species that might serve as final and intermediate hosts of the cestode in North Dakota. Later, animals were infected experimentally in the laboratory, and finally, cestodes from North Dakota were compared morphologically with series of specimens from other regions. The results of this work are reported in the present paper.

\section{Materials and Methods}

During 2-13 January, 1965, red foxes, Vulpes vulpes (Linnaeus), were collected in North Dakota as follows. Beginning $5 \mathrm{mi}$ south of the Canadian border, 12 parallels were laid out at 10 -mi intervals across eight northern counties (grid, Fig. 1). Foxes were to be collected, from airplanes, within a 4-mi radius of each of the 102 points established at $10-\mathrm{mi}$ intervals along lines 1 through 7 (from the north) and at $20-\mathrm{mi}$ intervals along the remainder. Foxes were not always available near the points of reference, and two animals were taken together on two occasions. Ninety-six animals were collected along the transects; 30 foxes were obtained mainly in southern counties in late January and February, 1965. Another series of 61 animals was collected during 1968-69. The relative density of foxes in the northern counties was estimated by counting those visible from the airplane within one-quarter of a mile on either side of each line at the time the collections were made.

The animals were retrieved at once, examined to determine sex and approximate age (juvenile or adult), and each gastrointestinal tract was tied at both ends and placed in a plastic bag labeled regarding point of reference and exact location. The viscera were frozen immediately and in this state shipped by air to the Arctic Health Research Center. After they were thawed, the organs were segregated and opened separately in water. The gastric mucosa was examined for nematodes, and the contents of the stomach were preserved for identification.

\footnotetext{
1Stephen H. Richards: Federal Aid Division, North Dakota Fish and Game Department, Bismarck, North Dakota; stationed at Jamestown, North Dakota. Research funded by Project W-67-R, Federal Aid to Wildlife Restoration Program.
} 
The suspension of intestinal contents was preserved by adding formalin to make a $10 \%$ concentration. To isolate parasites, the entire suspension from each animal was examined by use of a dissecting microscope in aliquots of about $5 \mathrm{ml}$ in $55-\mathrm{mm}$ Petri dishes. The glassware was washed or replaced after each use. Helminths were counted, segregated by species, and preserved. Cestodes and trematodes were stained in Semichon's acetic carmine or Ehrlich's acid hematoxylin, dehydrated in ethanol, cleared in terpineol, and permanently mounted on slides.

Small mammals were collected at various localities in North Dakota during 1965-69, mainly in snap-traps in habitat suitable for foxes; all were examined macroscopically for evidence of infection by the Iarval $E$. multilocularis. Except for a period in June 1965 when we worked together, the collecting was undertaken by Richards, who at each locality trapped for four successive nights. Carcasses of muskrats, Ondatra zibethicus (Linnaeus), which had been skinned at fur-buyers' establishments, were also examined by Richards.

The strain of E. multilocularis from North Dakota was maintained in experimental animals, laboratory-reared (with exceptions noted), at the Arctic Health Research Center. For exposure to infection, anesthetized rodents received embryophores introduced with a glass pipette into the stomach, and carnivores were directly fed tissue containing protoscolices. Tissues from infected rodents were fixed and preserved in $10 \%$ formalin. Sections were prepared by the paraffin-embedding method and stained in hematoxylin-eosin or by the periodic acid-Schiff (PAS) histochemical reaction.

\section{Results}

\section{THE FINAL HOST}

\section{Findings in Naturally Infected Foxes}

$E$. multilocularis occurred in $67(70 \%)$ of the 96 red foxes collected in the eight northern counties (Fig. 1). Numbers of cestodes in individual animals ranged from 1 to 4130 . Light infections were usual: 44 foxes $(66 \%)$ had 1 to 100 strobilae; $14(21 \%), 101$ to $500 ; 4(6 \%)$, 501 to 1000 ; and 4,1000 to 4130 . The rate of infection was lower $(27 \%)$ in the 30 foxes mainly from southern counties. Of the 61 animals obtained from January 1968 to December 1969 (examined by Richards), 30 (49\%) were infected. All localities are shown in Fig. 1.

As estimated mainly from the condition of the teeth, the 96 foxes included 27 adults, 68 juveniles, and 1 of undetermined age. Rates of infection in animals of the two age classes (67 and 70\%, respectively) did not differ significantly.

Whether strobilae in individual foxes contained gravid segments was determined by direct microscopic examination of the preserved material. Only those segments containing darkshelled, presumably infective embryophores were

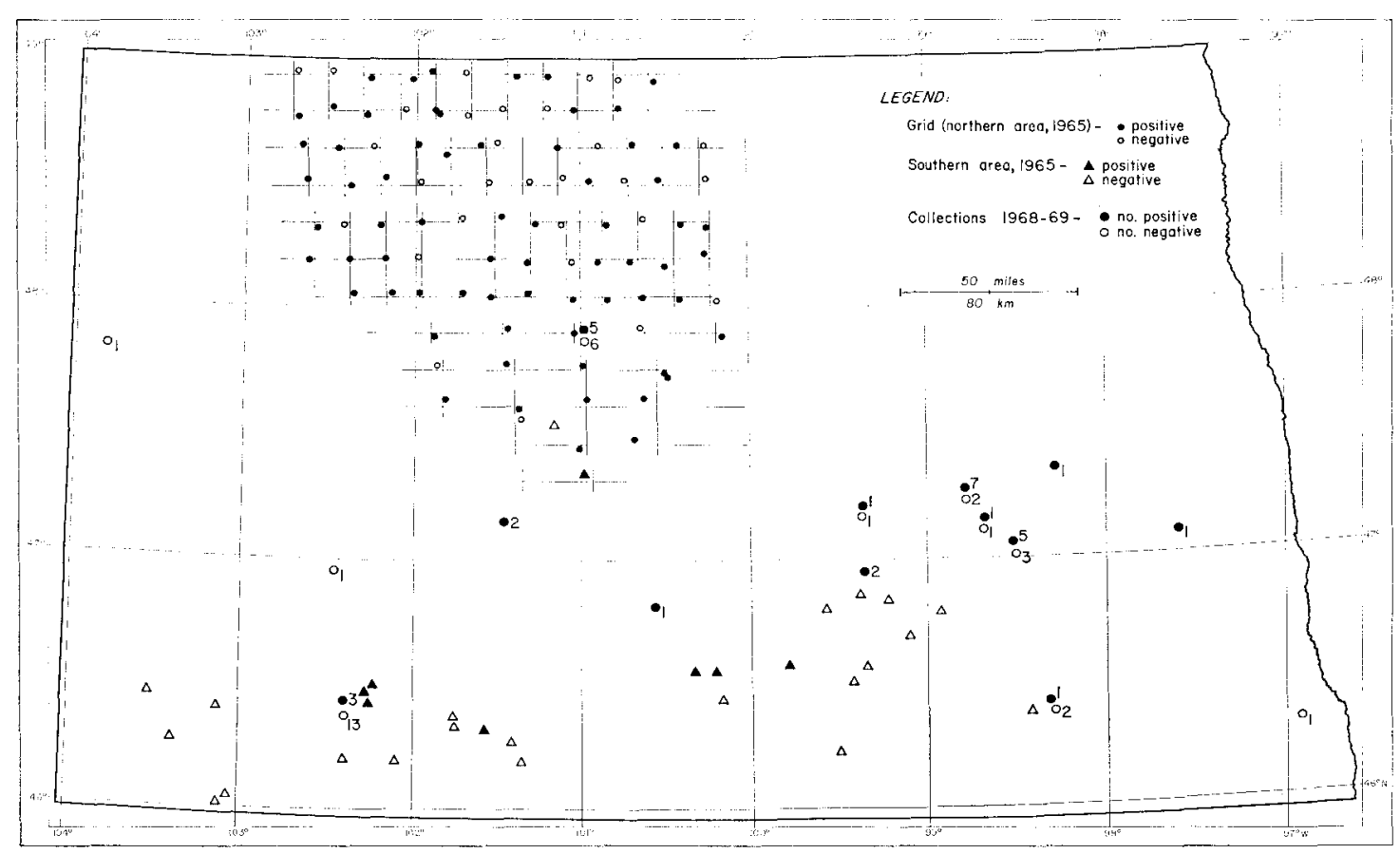

FIG. 1. Localities at which red foxes were collected in North Dakota. The symbols with numbers indicate county of origin only, for foxes collected during 1968-69. 
TABLE 1

Comparison of some morphological characteristics of $E$. multilocularis from various geographic regions

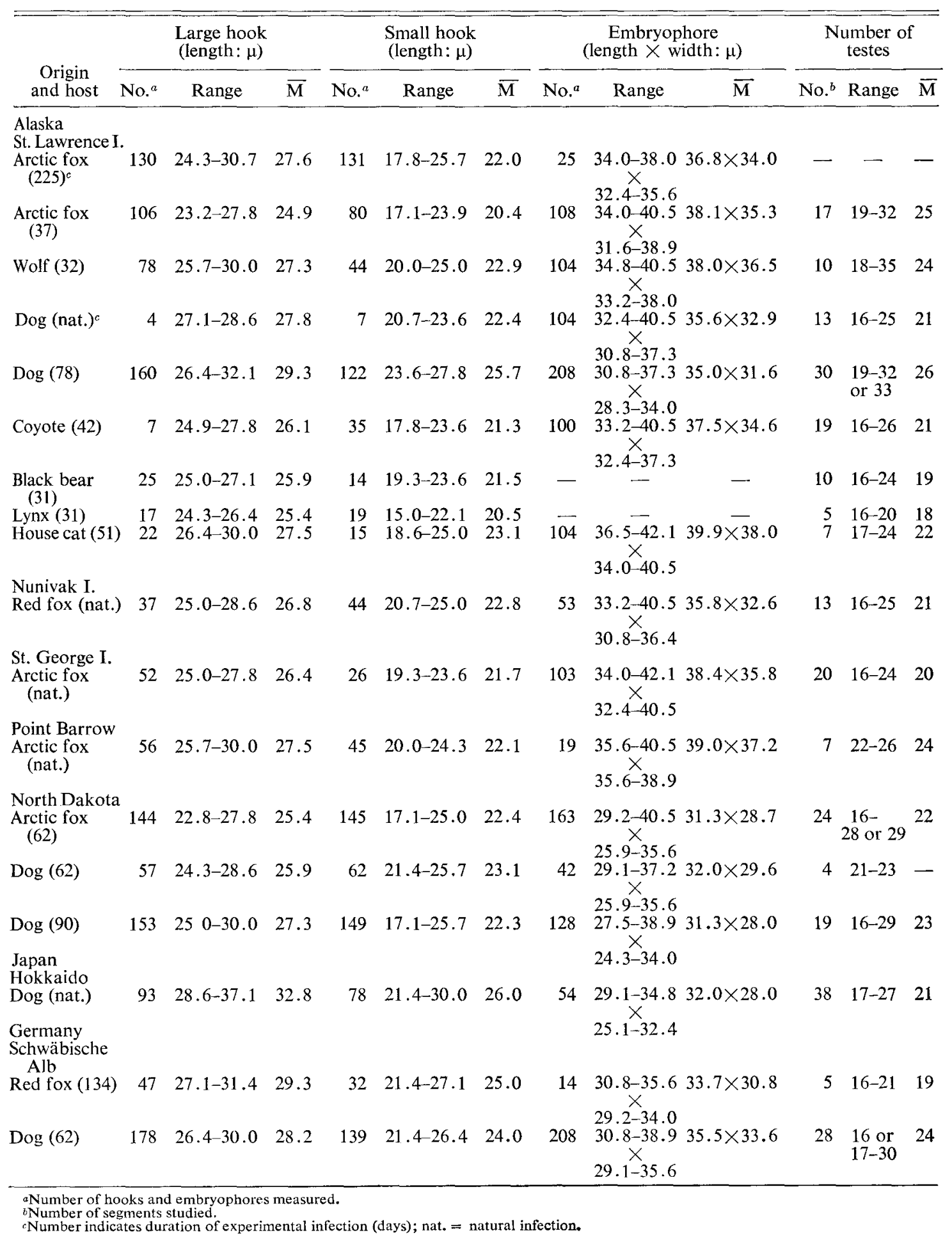


TABLE 2

Helminths recorded from 96 red foxes from northern North Dakota

\begin{tabular}{lcccc}
\hline \multicolumn{1}{c}{ Species } & $\begin{array}{c}\text { Number } \\
\text { infected }\end{array}$ & $\begin{array}{c}\% \\
\text { infected }\end{array}$ & $\begin{array}{c}\text { Number } \\
\text { present }\end{array}$ & $\begin{array}{c}\text { Mean } \\
\text { numbers }\end{array}$ \\
\hline Echinococcus multilocularis & 67 & 70 & $1-4130$ & 249 \\
Taenia crassiceps & 26 & 27 & $1-23$ & 4 \\
Mesocestoides kirbyi & 11 & 11 & $1-47$ & 8 \\
Alaria arisaemoides & 53 & 55 & $1-70$ & 12 \\
Alaria marcianae & 40 & 42 & $1-31$ & 6 \\
Toxascaris leonina & 93 & 97 & $1-95$ & $27^{a}$ \\
Physaloptera sibirica & 28 & 29 & $1-1548$ & $23^{b}$ \\
Uncinaria stenocephala & 2 & 2 & 1 & - \\
\hline aBased on 91 infected foxes. & & & &
\end{tabular}

considered to be gravid. Of the 65 infected foxes from which all cestodes had been preserved, $50(77 \%)$ contained gravid strobilae. None was gravid in $10(15 \%)$, and cestodes from the remaining five were not suitable for this determination. E. multilocularis requires at least 32 days to produce gravid segments (Rausch and Schiller 1956); thus, some of the cestodes in each of the 50 animals represented infections acquired before or during early December. (It is known that the presence of fully developed strobilae does not prevent suprainfection when additional exposures occur [Rausch unpublished].) Since many of the cestodes were fragmented, the proportion of gravid strobilae in each animal could not be determined.

\section{Morphological Characteristics}

Morphologically, the cestodes from North Dakota did not differ significantly from $E$. multilocularis from other regions (Table 1). We do not believe that they can be distinguished morphologically at the infraspecific level.

\section{Other Helminths in Foxes}

Including $E$. multilocularis, helminths representing eight species (three of Cestoda; two of Trematoda; three of Nematoda) were found in foxes from the northern area (Table 2). Multiple infections were usual, with a single species recorded from only seven foxes: two species were found in 16 animals; three in 31 ; four in 26 ; five in 13; six in 2 ; and seven in 1 animal. None had all of the eight recorded. Toxascaris leonina (von Linstow, 1902) was the most common, occurring in all but three. Immature ascarids at different developmental stages were found, usually with adults, in 51 of the 91 foxes for which the data were complete (specimens from 2 were inadvertently combined). Single specimens of Uncinaria stenocephala (Railliet, 1884) were found in each of two animals. Only Alaria arisaemoides Augustine and Uribe, 1927, produced macroscopically evident lesions. These

TABLE 3

Identification of contents of stomachs of 68 red foxes from northern North Dakota

\begin{tabular}{|c|c|c|}
\hline Species & $\begin{array}{l}\text { Occurrence } \\
\text { (no. } \\
\text { stomachs) }\end{array}$ & $\begin{array}{c}\% \\
\text { occurrence }\end{array}$ \\
\hline \multicolumn{3}{|l|}{ Mammals } \\
\hline Shrew, Sorex sp. & 3 & 4 \\
\hline Gopher, Thomomys sp. & 2 & 3 \\
\hline Hare, Lepus sp. & 13 & 19 \\
\hline Rabbit, Sylvilagus sp. & 4 & 6 \\
\hline $\begin{array}{l}\text { Deer mouse, } \\
\text { Peromyscus sp. }\end{array}$ & 11 & \\
\hline $\begin{array}{l}\text { Peromyscus sp. } \\
\text { Vole, Microtus sp. }\end{array}$ & 10 & $\begin{array}{l}16 \\
15\end{array}$ \\
\hline Rodents, unidentified & 10 & 15 \\
\hline Red fox, Vulpes vulpes & 1 & $>1$ \\
\hline Raccoon, Procyon lotor & 1 & $>1$ \\
\hline Mink, Mustela vison & $\hat{1}$ & $>1$ \\
\hline Skunk, Mephitis mephitis & 3 & 4 \\
\hline House cat & 1 & $>1$ \\
\hline Carrion (dog, 2 ; domestic & 13 & 19 \\
\hline \multicolumn{3}{|l|}{ Birds } \\
\hline \multicolumn{3}{|l|}{$\begin{array}{l}\text { Wild gallinaceous birds } \\
\text { (Hungarian partridge, } 8 \text {; } \\
\text { pheasant; ruffed grouse; }\end{array}$} \\
\hline Domestic chicken & 6 & 9 \\
\hline \multicolumn{3}{|l|}{ Passeriform birds } \\
\hline $\begin{array}{l}\text { (including Junco } \\
\text { and Hesperiphona) }\end{array}$ & 8 & 12 \\
\hline Unidentified birds & 3 & 4 \\
\hline \multicolumn{3}{|l|}{ Amphibia } \\
\hline Leopard frog & 1 & $>1$ \\
\hline \multicolumn{3}{|l|}{ Invertebrates } \\
\hline Grasshopper (Locustidae) & 1 & $>1$ \\
\hline \multicolumn{3}{|l|}{ Plants } \\
\hline $\begin{array}{l}\text { Berries and seeds (Linum, } \\
\text { Rosa, Elaeagnus, } \\
\text { Shepherdia) }\end{array}$ & 17 & 25 \\
\hline
\end{tabular}


trematodes, when numerous, formed aggregations 50 to $70 \mathrm{~mm}$ in length in the duodenum, from 200 to $450 \mathrm{~mm}$ posterior to the pylorus. The mucosa was moderately to severely congested in the area of attachment.

Findings in the 30 animals from southern counties differed significantly from those in the northern series. The frequency of occurrence of two species, T. leonina and Physaloptera sibirica Petrov and Gorbunov, 1931 (93 and 23\%, respectively), was similar to that in the northern series. Mesocestoides kirbyi Chandler, 1944, was more common $(20 \%)$, as was, apparently, $U$. stenocephala, found in three animals. $E$. multilocularis occurred less commonly in these foxes, and lower rates were obtained also for Taenia crassiceps (Zeder, 1800) and Alaria marcianae (La Rue, 1917) (13 and 17\%, respectively). Alaria arisaemoides was not found. One fox had no parasites, and nine harbored only a single species; two species were found in 11 animals, three in 5 , and four in 4 . Thus, multiple infections were less diversified than were those in many of the foxes from the northern area.

\section{Predator-Prey Relationships}

Remains of animals and (or) plants were present in the stomachs of 68 of the 96 foxes from the northern area. The identification of such remains provided an indication of the extent to which the foxes were preying upon rodents of species known to serve as intermediate host of E. multilocularis. Rodents were found in 33 stomachs $(48 \%)$. Also commonly represented were wild gallinaceous birds $(37 \%)$ and leporids $(25 \%)$. The species identified and the rates of their occurrence are shown in Table 3. The small amount of material obtained from foxes from the southern counties was inadequate for qualitative comparisons.

\section{Experimentally Infected Carnivores}

Dogs of a uniform strain (beagle) were routinely used as the final host in maintaining the cestodes in the laboratory, but arctic foxes,

TABLE 4

Results of experimental infections by two strains of $E$. multilocularis in carnivores

\begin{tabular}{|c|c|c|c|c|}
\hline \multicolumn{2}{|c|}{ Intermediate host } & \multicolumn{3}{|c|}{ Carnivore } \\
\hline Origin of larvae & $\begin{array}{c}\text { Duration of } \\
\text { infection, } \\
\text { days }\end{array}$ & Host and age & $\begin{array}{l}\text { Duration of } \\
\text { infection, } \\
\text { days }\end{array}$ & Result \\
\hline \multicolumn{5}{|l|}{ North Dakota strain } \\
\hline Clethrionomys rutilus & 114 & Dog, 74 days & 52 & - \\
\hline C. rutilus & 114 & Dog, 74 days & 52 & - \\
\hline C. rutilus & 197 & Dog, 79 days & 62 & + \\
\hline C. rutilus & 197 & $\begin{array}{l}\text { Arctic fox, } \\
\text { ca. } 2 \text { years }\end{array}$ & 62 & + \\
\hline Peromyscus maniculatus & 112 & Cat, 35 days & 61 & - \\
\hline \multirow{2}{*}{ P. maniculatus } & 112 & Cat, 35 days & 61 & - \\
\hline & & Dog, 68 days & 61 & + \\
\hline P. maniculatus & $\begin{array}{l}\text { Natural } \\
\text { infection }\end{array}$ & Red fox, adult & 61 & + \\
\hline \multirow[t]{3}{*}{ Sigmodon hispidus } & $>200$ & Dog, 84 days & 90 & + \\
\hline & & Cat, adult & 48 & $f^{a}$ \\
\hline & & Cat, adult & 48 & $t^{a}$ \\
\hline \multirow{2}{*}{$\begin{array}{l}\text { St. Lawrence Island strain } \\
\text { Microtus oeconomus }\end{array}$} & & & & \\
\hline & $\begin{array}{l}\text { Natural } \\
\text { infection }\end{array}$ & Dog, 54 days & 52 & + \\
\hline M. oeconomus & 112 & $\begin{array}{c}\text { Coyote, } 20 \\
\text { months }\end{array}$ & 42 & + \\
\hline M. oeconomus & 192 & Dog, 236 days & 53 & + \\
\hline C. rutilus & 61 & Dog, 41 days & 61 & + \\
\hline C. rutilus & 162 & Dog, 6 months & 121 & + \\
\hline C. rutilus & 162 & Arctic fox, & 130 & + \\
\hline C. rutilus & 69 & Dog, 111 days & 63 & + \\
\hline C. rutilus & 284 & Dog, 72 days & 60 & + \\
\hline C. rutilus & 210 & Dog, $<6$ months & 56 & + \\
\hline & 210 & Dog, $<6$ months & 41 & + \\
\hline & 210 & Dog, $<6$ months & 57 & + \\
\hline
\end{tabular}

aTwo cestodes present. 
Alopex lagopus (Linnaeus), and house cats also were exposed to infection by isolates of $E$. multilocularis from North Dakota and Alaska (St. Lawrence Island). Because there is no uniformity in numbers of protoscolices produced in larvae developing in rodents of different species, it was not thought practicable to determine numbers given to individual carnivores. In all cases the quantity of tissue given was considered adequate to produce numerous cestodes in susceptible animals.

The numbers exposed were too small to permit reliable conclusions about the comparative infectivity of the two strains; however, fewer became infected by that from North Dakota (Table 4). Two cats exposed to the latter did not become infected, and only two immature cestodes were found in each of two others, each of which had received a $15 \times 10 \mathrm{~mm}$ mass of larvae from the peritoneal cavity of a cotton rat, Sigmodon hispidus Say and Ord. The strain from St. Lawrence Island developed more readily in cats. Four fed larvae from Microtus pennsylvanicus (Ord) were found to be infected 32 to 53 days later (fully developed larvae from voles of this species contain 136 to 226 protoscolices per milligram of tissue), and embryophores from one of these (examined 51 days after exposure) produced larvae in a brown lemming, Lemmus sibiricus (Kerr). Two cats that had received masses of larvae weighing 3.8 and $3.2 \mathrm{~g}$, respectively, from another such vole were found to be infected when examined after 46 days. In these six cats, however, comparatively few cestodes were found. Wobeser (1971) found E. multilocularis in 3 of 131 free-ranging house cats in the vicinity of Saskatoon, Saskatchewan; the two most heavily infected each had about 30 to 50 strobilae. House cats seem clearly to be less suitable than dogs as the final host of the two North American strains of E. multilocularis. It is of interest that Vogel $(1957$, p. 419) obtained a massive infection in a cat with the European strain of this cestode.

\section{THE INTERMEDIATE HOST}

\section{Findings in Wild Rodents}

The 1899 small mammals collected at 26 localities within the state (Fig. 2), mainly in habitat suitable for red foxes, represented 10 species. All were examined for the presence of the larval E. multilocularis (Table 5), which was recorded only from deer mice, Peromyscus maniculatus (Wagner), and from voles, $M$.

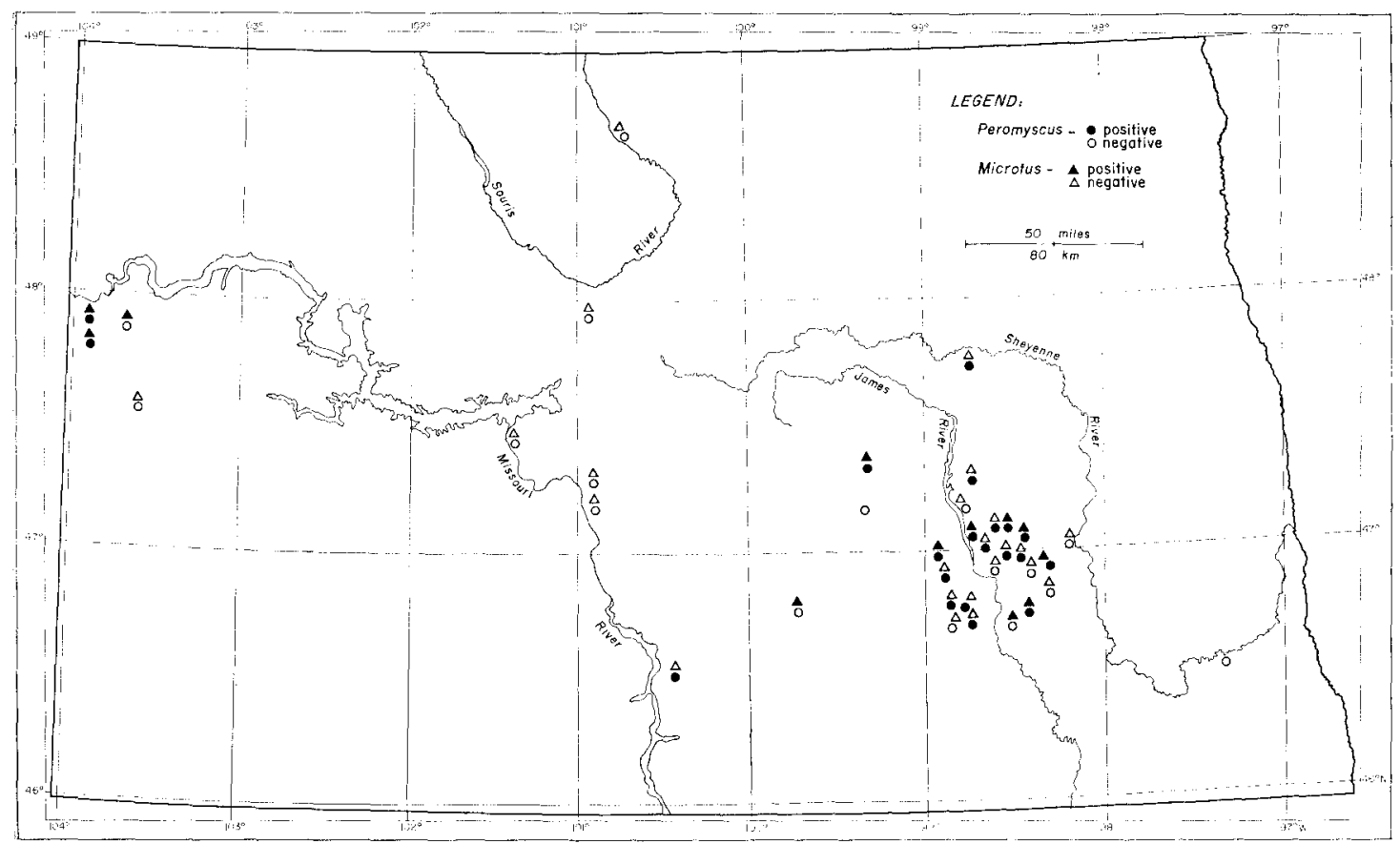

FIG. 2. Localities at which voles and deer mice were collected in North Dakota. 
pennsylvanicus. Both have been reported as natural hosts of the larval E. multilocularis by Leiby (1965).

Larvae of $E$. multilocularis were not found in any of 12142 muskrats, $O . z$. cinnamominus (Hollister), trapped in eastcentral North Dakota and examined during 1966-69. The larval stage of another taeniid cestode, Taenia taeniaeformis (Batsch, 1786), occurred commonly in these animals.

\section{Characteristics of the Larval Cestode}

In morphological characteristics, larvae in naturally infected voles ( $M$. pennsylvanicus) were not distinguishable from those produced experimentally in animals of the same species by the strain of $E$. multilocularis from St. Lawrence Island (Ohbayashi et al. 1971). Individual vesicles ranged to $4-5 \mathrm{~mm}$ in diameter, and in fully developed larvae, protoscolices and calcareous corpuscles were abundant. Extensive infections, involving one or more hepatic lobes, were not unusual, and in one vole trapped in Stutsman County the liver had been almost completely replaced by the larvae.

In the infected deer mice, we usually found a few thin-walled, large vesicles (to $8 \mathrm{~mm}$ in diameter), of which the germinal layer was relatively thin, and in which protoscolices were fewer. Calcareous corpuscles were few. Involvement of the liver was often restricted to a single lobe.

Findings in Experimentally Infected Rodents

On 23 October 1965, a red fox provided by the Bismarck Zoo was fed the infected liver of a

TABLE 5

Small mammals from North Dakota examined for the presence of the larval E. multilocularis

\begin{tabular}{lccc}
\hline \multicolumn{1}{c}{ Species } & $\begin{array}{c}\text { Number } \\
\text { examined }\end{array}$ & $\begin{array}{c}\text { Number } \\
\text { infected }\end{array}$ & $\begin{array}{c}\% \\
\text { infected }\end{array}$ \\
\hline $\begin{array}{l}\text { Sorex cinereus } \\
\text { Blarina brevicauda }\end{array}$ & 41 & - & - \\
$\begin{array}{l}\text { Zapus hudsonilus } \\
\text { Reithrodontomys }\end{array}$ & 70 & - & - \\
$\begin{array}{l}\text { megalotis } \\
\text { Mus musculus }\end{array}$ & 202 & - & - \\
$\begin{array}{l}\text { Peromyscus maniculatus } \\
\text { Clethrionomys gapperi }\end{array}$ & 1080 & - & - \\
Microtus pennsylvanicus & $467^{a}$ & -29 & - \\
Citellus tridecemlineatus & 17 & - & - \\
C. richardsoni & 1 & - & - \\
\hline \multicolumn{2}{c}{ aTotal number and number infected include voles obtained by all } \\
methods.
\end{tabular}

deer mouse trapped in Wells County, North Dakota, and was shipped immediately to the Arctic Health Research Center. Sixty-one days after exposure, nine cestodes were obtained from the small intestine. Gravid segments from these were given to red-backed voles, Clethrionomys rutilus dawsoni (Merriam) (one segment to each of three voles; two to a fourth). All were found to be infected 80 to 197 days later.

The vole receiving two gravid segments was found, after 197 days, to have a single mass of vesicles in the right median hepatic lobe. This mass was divided and fed to a 79-day-old dog and to an arctic fox born the previous year at the University of Alaska Fur Experimental Farm, Petersburg. At autopsy 62 days later, gravid cestodes were collected from both animals. Embryophores from cestodes in the dog did not produce infections in red-backed voles and deer mice, but those from the fox were infective. Thereafter, the cestode was transmitted in laboratory animals through several generations. The strain of $E$. multilocularis from St. Lawrence Island was maintained concurrently in other animals.

In an attempt to demonstrate possible differences in degree of susceptibility of rodents to the strains of $E$. multilocularis from North Dakota and St. Lawrence Island, 291 animals of 13 species were exposed to infection (Table 6). The gravid segments used were selected with the aid of a dissecting microscope, but the infectivity of the eggs contained could not be predetermined. This variable notwithstanding, some differences between the strains eventually were indicated. Findings in some of the animals that became infected by the North Dakota strain are described below. Host-related differences in histogenesis of the larval cestode and in the characteristics of the tissue reaction evoked have been given in detail by Ohbayashi et al. 1971.

\section{Clethrionomys rutilus (Pallas)}

The development of the larval $E$. multilocularis (SLI strain) in red-backed voles is characterized by rapid proliferation and growth of vesicles, with formation of protoscolices beginning about 30 days after exposure. The North Dakota strain produced less massive infections than expected from numbers of embryophores given, but no differences were noted in developmental characteristics of the larvae. 
Microtus oeconomus operarius (Nelson)

In voles of this subspecies, the development of the larval cestode of North Dakota origin was retarded as compared with that occurring with the St. Lawrence Island strain. In four voles 30 days after exposure, small numbers of discrete hepatic foci $(0.5$ to $1.5 \mathrm{~mm}$ in diameter) were found, each focus containing single cysts $(0.260$ to $0.5 \mathrm{~mm}$ in diameter) in which there was little evidence of exogenous budding. In larger cysts, the germinal layer was thin but well developed. The cuticle was about $0.002 \mathrm{~mm}$ in thickness. The dense, fibrous adventitia, about $0.008 \mathrm{~mm}$ in thickness, immediately surrounded each vesicle and graded into tissue containing only scattered fibers. The outer portion of the adventitia contained numerous histiocytes. In some foci, less advanced in development, remains of a central mass of uncalcified detritus were present, the vesicles were surrounded by a thin epithelioid zone, and no calcareous corpuscles were observed.

In one vole 62 days after exposure, the hepatic foci contained multivesicular larvae, with individual cysts to about $3 \mathrm{~mm}$ in diameter.
In the thin germinal layer were a few scattered aggregations of cells that represented earlystage Anlagen of brood capsules. Again, no calcareous corpuscles were observed.

One animal died 546 days after exposure. In one hepatic lobe were two cysts about $10 \mathrm{~mm}$ in diameter, both of which had ruptured and collapsed, and an adjacent area in which small cysts were proliferating. The large ruptured cysts were unilocular, with a cuticular layer from 0.015 to $0.030 \mathrm{~mm}$ in thickness, and surrounded by a densely fibrous adventitia from 0.060 to $0.300 \mathrm{~mm}$ in thickness. Some brood capsules and their protoscolices showed evidence of degenerative changes. Calcareous corpuscles were abundant. The hepatic tissue was severely congested, with focal areas of fatty metamorphosis. No intraabdominal nodules or other metastases were present.

Five 58-day-old voles of this subspecies were inoculated intraperitoneally with fragments of brood capsules and other tissues from the large cysts. After 257 days, a single vesicle, $5 \times 3 \mathrm{~mm}$, containing fully developed protoscolices, was found in the pelvic cavity of one; small nodules

TABLE 6

Results of experimental infections by two strains of E. multilocularis in rodents

\begin{tabular}{|c|c|c|c|c|c|c|c|c|c|c|c|c|c|}
\hline \multirow{4}{*}{$\begin{array}{l}\text { Species } \\
\text { (rodent) } \\
\text { exposed }\end{array}$} & \multicolumn{11}{|c|}{ Source of embryophores } & & \\
\hline & \multicolumn{4}{|c|}{ North Dakota strain } & \multicolumn{7}{|c|}{ St. Lawrence Island strain } & & \\
\hline & \multirow{2}{*}{$\begin{array}{l}\text { Red } \\
\text { fox, } \\
\text { nat. } \\
\text { inf. }\end{array}$} & \multirow{2}{*}{$\begin{array}{l}\text { Arctic } \\
\text { fox, } \\
\text { exptl. } \\
62 \\
\text { day }\end{array}$} & \multirow{2}{*}{$\begin{array}{c}\text { Dog, } \\
\text { exptl. } \\
90 \\
\text { day }\end{array}$} & \multirow{2}{*}{$\begin{array}{c}\text { Dog, } \\
\text { exptl. } \\
62 \\
\text { day }\end{array}$} & \multirow{2}{*}{$\begin{array}{l}\text { Arctic } \\
\text { fox, } \\
\text { nat. } \\
\text { inf. }\end{array}$} & \multirow{2}{*}{$\begin{array}{l}\text { Arctic } \\
\text { fox, } \\
\text { nat. } \\
\text { inf. }\end{array}$} & \multirow{2}{*}{$\begin{array}{l}\text { Arctic } \\
\text { fox, } \\
\text { exptl. } \\
130 \\
\text { day }\end{array}$} & \multirow{2}{*}{$\begin{array}{c}\text { Coyote } \\
\text { exptl. } \\
42 \\
\text { day }\end{array}$} & \multirow{2}{*}{$\begin{array}{c}\text { Dog, } \\
\text { exptl. } \\
63 \\
\text { day }\end{array}$} & \multirow{2}{*}{$\begin{array}{c}\text { Dog, } \\
\text { exptl. } \\
60 \\
\text { day }\end{array}$} & \multirow{2}{*}{$\begin{array}{c}\text { Dog, } \\
\text { exptl. } \\
63 \\
\text { day }\end{array}$} & \multicolumn{2}{|c|}{ Totals } \\
\hline & & & & & & & & & & & & ND & SLI \\
\hline $\begin{array}{l}\text { Dicrostonyx } \\
\text { groenlandicus } \\
\text { stevensoni }\end{array}$ & - & $0 / 6^{a}$ & $0 / 7$ & 一 & $4 / 4$ & - & - & - & - & - & - & $0 / 13$ & $4 / 4$ \\
\hline $\begin{array}{l}\text { D. g. nelsoni } \\
\text { D. g. richardsoni }\end{array}$ & - & 一 & - & - & $3 / 3$ & - & - & - & - & - & $1 / 4$ & - & $4 / 7$ \\
\hline $\begin{array}{l}\text { D. g. richardsoni } \\
\text { Lemmus sibiricus }\end{array}$ & - & $\overline{0}$ & $\overline{0.6}$ & 一 & $2 / 4$ & - & - & - & - & - & $0 / 2$ & $\overline{0}$ & $2 / 6$ \\
\hline $\begin{array}{l}\text { Lemmus sibiricus } \\
\text { L. lemmus }\end{array}$ & - & $0 / 9$ & $0 / 6$ & 一 & $4 / 4$ & 一 & 一 & 一 & 一 & 一 & - & $0 / 15$ & $4 / 4$ \\
\hline $\begin{array}{l}\text { L. lemmus } \\
\text { Clethrionomys rutilus }\end{array}$ & $\overline{2 / 4}$ & $1 / 3$ & $0 / 6$ & $\bar{x}$ & $3 / 4$ & - & $\overline{677}$ & $\overline{0.12}$ & $\overline{4}$ & $\overline{0.15}$ & $\overline{710}$ & $1 / 9$ & $3 / 4$ \\
\hline $\begin{array}{l}\text { Clethrionomys rutilus } \\
\text { Microtus oeconomus }\end{array}$ & $\begin{array}{l}2 / 4 \\
2 / 6\end{array}$ & $2 / 6$ & $1 / 6$ & $0 / 4$ & $5 / 5$ & $\ldots$ & $6 / 7$ & $9 / 12$ & $4 / 4$ & $9 / 15$ & $7 / 10$ & $5 / 20$ & $40 / 53$ \\
\hline $\begin{array}{l}\text { Microtus oeconomus } \\
\text { M. miurus }\end{array}$ & $2 / 0$ & $3 / 10$ & 二- & 一 & $7 / 8$ & $3 / 3$ & $3 / 10$ & $3 / 3$ & - & - & $4 / 6$ & $7 / 16$ & $20 / 30$ \\
\hline $\begin{array}{l}\text { M. murus } \\
\text { M. abbreviatus }\end{array}$ & - & $\underline{0 / 10}$ & - & - & - & 二 & $\underline{0 / 9}$ & $\underline{0 / 3}$ & $\underline{0 / 0}$ & 二 & $\begin{array}{l}0 / 4 \\
0 / 10\end{array}$ & $\underline{0 / 10}$ & $\begin{array}{l}0 / 22 \\
0 / 10\end{array}$ \\
\hline Ondatra zibethicus & $1 / 3$ & $\ldots$ & - & - & - & - & - & - & - & - & - & $1 / 3$ & - \\
\hline $\begin{array}{l}\text { Peromyscus } \\
\text { maniculatus }\end{array}$ & & $4 / 10$ & $1 / 4$ & $0 / 6$ & 一 & $0 / 8$ & $1 / 5$ & - & $0 / 5$ & $0 / 6$ & - & $5 / 20$ & $1 / 24$ \\
\hline Citellus parryi & - & $0 / 2$ & - & 一 & - & $\overline{2}$ & - & - & - & - & - & $0 / 2$ & $\overline{0}$ \\
\hline C. tridecemlineatus & - & $0 / 5$ & - & - & - & $3 / 3$ & 一 & - & - & - & - & $0 / 5$ & $3 / 3$ \\
\hline C. franklini & - & - & 一 & - & - & $1 / 10$ & - & 一 & - & - & 一 & - & $1 / 10$ \\
\hline C. richardsoni & 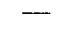 & - & - & - & - & $0 / 1$ & - & - & - & - & - & - & $0 / 1$ \\
\hline
\end{tabular}


of amorphous tissue, apparently the remains of dead larvae, were present intraperitoneally in two others.

\section{Lemmus lemmus (Linnaeus)}

In a lemming 34 days after exposure, multivesicular larvae were present in one hepatic lobe. The individual cysts, as much as $6 \mathrm{~mm}$ in diameter, were surrounded by a thin germinal layer with a few cellular aggregations probably representing early-stage Anlagen of brood capsules. The cuticle, about $0.003 \mathrm{~mm}$ in thickness, was well defined. The characteristics and thickness of the adventitia varied widely in different foci. Calcareous corpuscles were not observed.

Ondatra zibethicus cinnamominus (Hollister)

An adult muskrat trapped in North Dakota contained a single hepatic focus when examined 136 days after exposure. This animal might have become infected naturally. The focus, $30 \times 28 \times 19 \mathrm{~mm}$, lay superficially in the hepatic tissue. In the liver, also, were three ensysted larvae of Taenia taeniaeformis, one cont.guous with the larval E. multilocularis. When transected, the latter focus was found to consist of a central necrotic cavity about $8 \mathrm{~mm}$ in diameter, around which were several irregularly shaped vesicles as much as $15 \mathrm{~mm}$ in diameter. Within the larger cavities were 23 free daughter cysts, 0.5 to $4 \mathrm{~mm}$ in diameter, some of which were multivesicular. The smallest were thinwalled and transparent; others contained calcareous corpuscles; and in the largest, fully developed protoscolices occurred singly within small brood capsules. Attached to some of the larger cysts were aggregations of minute vesicles. In one mass, a vesicle about $0.5 \mathrm{~mm}$ in diameter contained numerous trabeculae.

Microscopically, the large cysts were found to have an irregular, much folded, and distinctly laminated cuticle in thickness from 0.035 to $0.130 \mathrm{~mm}$. The outer part of this layer was necrotic and more darkly stained, with some areas of calcification. Sequestral fragments of cuticular tissue were numerous and usually surrounded by aggregations of eosinophils. Within fissures and cavities in the cuticle were many eosinophils, some of which occurred in a single row along narrow fissures. In most areas, a thin epithelioid zone bordered the outer surface of the cuticle, and a few giant cells were present. Tissue enclosed within folds of cuticle was necrotic or undergoing calcification; in some areas, masses of degenerating eosinophils could still be faintly discerned. The adventitia, 0.090 to $0.260 \mathrm{~mm}$ in thickness, was loose and infiltrated by eosinophils and histiocytes. Within and peripheral to the adventitia were focal aggregations of such cells. The germinal layer was thin and acellular, with relatively few calcareous corpuscles. Brood capsules and protoscolices were few, scattered, and often degenerating. Some protoscolices were undergoing vesiculation, evidently metamorphosing to daughter cysts. The latter were surrounded by a cuticular layer from 0.008 to $0.038 \mathrm{~mm}$, the thickness depending upon their size and state of development. One of the larger daughter cysts contained degenerating protoscolices, with areas of calcification.

The contiguous encysted larva of $T$. taeniaeformis was normally developed. The cyst, composed of a densely fibrous layer about $0.040 \mathrm{~mm}$ in thickness, external to which were focal accumulations of histiocytes, contained fluid within which were large numbers of eosinophils.

Peromyscus maniculatus bairdi (Hoy and Kennicott)

The experimental animals were laboratoryreared from stock trapped near Jamestown, North Dakota. In these rodents, the larval cestode produced comparatively large (to $10 \mathrm{~mm}$ ), often unilocular cysts that were characteristically thin-walled; the scattered brood capsules contained comparatively few protoscolices (see also Leiby et al. 1969, Fig. 6).

In an animal examined 30 days after exposure to infection by the North Dakota strain, the liver held numerous foci within which were single cysts up to $0.750 \mathrm{~mm}$ in diameter, each with extremely thin walls. The cysts were surrounded by an epithelioid zone about $0.060 \mathrm{~mm}$ in thickness, the inner portion infiltrated by eosinophils. The external fibrous zone was about $0.015 \mathrm{~mm}$ thick. Peripherally, the adjacent tissue was infiltrated by histiocytes and small round cells to a depth of about $0.115 \mathrm{~mm}$.

In four deer mice 113 days after exposure, single cysts were found in two; one had multiple cysts in one hepatic lobe; and one, multiple 
cysts in two lobes. The largest cysts were as much as $8 \mathrm{~mm}$ in diameter. Thickness of the fibrous adventitia was 0.040 to $0.050 \mathrm{~mm}$. Scattered on the thin germinal layer were earlystage brood capsules. No calcareous corpuscles were observed.

\section{Discussion}

During the winter of 1964-65, red foxes were numerous in northern North Dakota. Aerial counts made during January 1965, while the foxes were being collected, indicated an average density of at least one animal for every 2 sq. mi in the northern counties (Arthur W. Adams, unpublished).

The results of trapping in spring and summer, 1965, indicated that deer mice and voles were also generally numerous, and we believe that they had probably been so during the preceding winter. Remains of rodents were present in $33(48 \%)$ of the 68 foxes taken in January (Table 3). Twenty-one stomachs contained voles or deer mice, and the unidentified rodents in 10 probably were mainly of these species. Pocket gophers, Thomomys sp., were found in two. It is difficult to account for the presence in winter of a frog, Rana pipiens Schreber, and of a snake, Thamnophis sirtalis Linnaeus, that we found in two foxes. Other animals that may make up part of the foxes' diet are usually unavailable in winter (e.g., jumping mice, Zapus hudsonius (Zimmermann), and ground squirrels, Citellus spp., which are hibernating).

Although our trapping was somewhat selective for voles, the much larger numbers of deer mice captured (Table 5) indicated that the latter were the more abundant during 1965-69. Deer mice occupy more diverse habitats than do voles, which occur mainly in lowlands where there is heavy cover of grasses. The finding of deer mice and voles in about equal proportions in the stomachs of foxes taken in January is perhaps the result of their preferential hunting for voles. Scott (1947, p. 464) considered that red foxes in central Iowa preferred voles to deer mice. The occasional finding of dead deer mice at fox dens in North Dakota also suggests that these rodents are not preferred food; uneaten voles were not observed at such dens. At the latitude of North Dakota $\left(46^{\circ}-49^{\circ} \mathrm{N}\right)$, voles may become increasingly less vulnerable to predation by foxes with increasing depth of snow cover. The increasing consumption of deer mice by red foxes in winter in central Iowa, as observed by Scott (1947, p. 446), might have been related in part to decreasing availability of voles. On St. Lawrence Island (Bering Sea), arctic foxes have little success in capturing voles, Microtus oeconomus (Pallas), after November in most years, because of the protective effect of snow cover (F. H. Fay, unpublished).

In North Dakota and adjacent regions, both deer mice and voles serve as intermediate hosts of E. multilocularis; the former appears to have been the more important in 1965-69 (Leiby et al. 1970). Published records and our findings indicate that rates of infection differ widely from locality to locality, or even within comparatively small areas. Rates recorded in deer mice are as follows: 1 infected $(2 \%)$ of 52 animals in southwestern Minnesota (Carney and Leiby, 1968); $63(22 \%)$ of 283 near Edmonton, Alberta (Holmes et al. 1971); 1 (4\%) of 25 near Winnipeg, Manitoba (Lee 1969); $15(15 \%)$ of 99 near Winnipeg (Leiby et al. 1969); 197 (5.9\%) of 3340 in North Dakota (Leiby et al. 1970); and $32(3 \%)$ of 1080 in North Dakota (present study). Rates in the fewer voles examined are $1(\mathrm{ca} .1 \%)$ of 114 near Saskatoon, Saskatchewan (Hnatiuk 1966); none of 325 in southwestern Minnesota (Carney and Leiby 1968); $18(3.2 \%)$ of 566 in North Dakota (Leiby et al. 1970); and 17 (3.8\%) of 445 in North Dakota (present study). Leiby et al. (1970) reported rates of infection of $4.8 \%$ in 4209 deer mice and $1.9 \%$ in 1033 voles collected in five states.

When these data for the animals collected in North Dakota are combined, rates in deer mice and voles are 5.2 and $3.5 \%$, respectively. But because of the relatively small numbers of animals considered, the effects of different methods of trapping, and inability to evaluate such factors as seasonal variation in rates related to age composition of the populations, a valid comparison of findings in the two species cannot be made. One example of the effects of selective trapping might be given. In Stutsman County (southeastern North Dakota), where voles were abundant during the summer of 1969 , trapping for 4 nights around two dens (ca. 37 meters apart) occupied by a family of foxes produced 12 voles, of which 2 were infected. 
Trapping there was continued, in an effort to capture all of the voles in the area. As a result, 21 more were taken, of which 11 were infected, and 1 infected vole was caught by hand. (These 22 animals were not included in calculating the rate given above.)

The incidence of infection in red foxes in North Dakota would presumably vary seasonally, as a function of seasonal changes in rates in deer mice and voles, and of the degree to which the respective rodents are used by foxes during different times of the year. In arctic foxes on St. Lawrence Island, a maximum rate of about $90 \%$ is attained annually in autumn; thereafter, the cestodes are gradually eliminated until spring, when the rate for the year is lowest (ca. 30\%) (Fay and Rausch 1966). There, in December, when the largest samples were obtained, the average rate in arctic foxes for a 7 -year period was about $83 \%$. The small numbers of voles in the winter diet of arctic foxes largely affect the possibility of reinfection during this season. In the summer, about $40 \%$ of the larvae in voles contain infective protoscolices (Fay 1970). The rate of infection in voles, combining all age classes (based upon 1453 animals), was about $10 \%$ during the months of June through August on St. Lawrence Island (F. H. Fay, unpublished). The proportion of voles infected by the larval cestodes is highest in spring, when the population is made up of older individuals, and before the annual period of reproduction begins. The pattern of seasonal changes in incidence in rodents and foxes may be quite different under other ecological conditions; for example, in the vicinity of Tsiteli-Tskaro, in the eastern part of the Georgian SSR (lat. ca. $41^{\circ} \mathrm{N}$ ), maximum annual rates were observed in autumn in voles, Microtus socialis (Pallas), and in spring in red foxes ( 4 and $30 \%$, respectively) (Kurashvili 1966).

The rate of infection $(70 \%)$ recorded in red foxes collected in North Dakota during January was similar to that determined for arctic foxes on St. Lawrence Island for the same month. In the arctic foxes, cestodes acquired during summer and autumn were being eliminated, and the rate of infection was declining. But in the red foxes, the rate might have been approaching the annual maximum if voles and deer mice were being increasingly used by them. In Iowa, Scott and
Klimstra (1955, Figs. 10 and 11) found that the greatest consumption of these rodents for the year took place during late winter and spring. Richards and Hine (1953) reported comparable findings. Red foxes in North Dakota might be expected to have a similar seasonal pattern in diet. The lower rates of infection in red foxes in North Dakota reported by Leiby and his coworkers, presumably based upon collections mainly in winter, may be in part attributable to differences in method of examination (see Leiby et al. 1970 , p. 1141).

Our findings and those of Leiby et al. (1970) indicate that there was a striking contrast in numbers of cestodes in the infected red foxes (see above) as compared with arctic foxes taken in winter (December) on St. Lawrence Island. In 50 infected arctic foxes, taken at random from a large series, the number of cestodes per animal (determined from aliquots from uniform suspensions) ranged from about 100 to 160000 , with an average of about 28280 (Fay and Rausch, unpublished). Of these 50 , only 12 had less than 1000 cestodes, and 30 had more than 5000 . The smaller numbers in the red foxes might indicate that the cestodes were being lost, and that reinfection was infrequent. Also, larvae in deer mice would contain fewer protoscolices as compared with those in voles.

However, a possibility to be considered is that red foxes are less suitable than arctic foxes as hosts of E. multilocularis. That such might be the case was indicated by results obtained by Rausch and Schiller (1956) and by Vogel (1957, p. 450), using the strain of cestode from St. Lawrence Island. Of a series of foxes taken on Nunivak Island (off the western coast of Alaska) during late December and early January, 13 arctic foxes and 3 red foxes harbored $E$. multilocularis. In the former, numbers of cestodes ranged from about 1100 to 56650 , with an average of about 10150 ; one of the red foxes had about 50 cestodes, and the other two about 250 each (Fay and Rausch, unpublished). Only nine cestodes were obtained by us, in the present study, in a red fox that had received welldeveloped hepatic cysts from a naturally infected deer mouse. Although comparatively few protoscolices are produced by larvae in this species, a much larger number of cestodes would have been expected. In contrast, two masses of vesicles, 
each derived from a single embryophore in redbacked voles, $C$. rutilus, experimentally infected by the St. Lawrence Island strain, when fed to two dogs, produced 52790 and 64240 cestodes, respectively (Rausch, unpublished). Small numbers of these cestodes were recorded also in red foxes in the Kamchatsk Oblast', in eastern Siberia (Kozlov 1961); however, red foxes in central Europe may have massive infections (Mendheim 1953).

A comparison of results obtained when rodents of various species were exposed to infection by embryophores of cestodes from St. Lawrence Island and from North Dakota indicated that the two strains differ in degree of infectivity for some species. Although a smaller proportion of red-backed voles became infected by the North Dakota strain, no differences in development in larvae of the two strains were apparent in this host. In $M$. o. operarius, the development of the larvae of the North Dakota strain seemed clearly to be retarded. The absence of metastases in an animal which had been infected for 18 months and the failure of tissue inoculated intraperitoneally to proliferate in voles of this species were also indicative of a relatively unfavorable parasite-host relationship.

A higher proportion of deer mice, P. m. bairdi, became infected by the North Dakota strain, but compared with that seen in voles, the early tissue reaction evoked in deer mice by larvae of both strains was severe, the growth of the cysts was inhibited, and exogenous proliferation was markedly less. The length of time required to produce infective protoscolices in $P . m$. bairdi seems to be not less than 3 months, as compared with 2 months in some of the arvicoline rodents. The absence of calcareous corpuscles in larvae developing in deer mice also points to an unfavorable parasite-host relationship (Ohbayashi et al. 1971).

Leiby and Nickel (1968) reported that the larvae were multivesicular in five deer mice examined 30 to 35 days after exposure, and that the formation of protoscolices had begun in one. However, these animals, trapped near Newcastle, Wyoming, were of a different subspecies, $P$. maniculatus osgoodi Mearns (see Hall and Kelson 1959, map 355), in which the larval cestode may develop more rapidly. Other attempts to infect six deer mice of another subspecies, $P, m$. artemisiae (Rhoads), were unsuccessful, but a specimen of $P$. truei (Shufeldt) became infected, and the larvae contained immature protoscolices 44 days after exposure (Ohbayashi et al. 1971). The degree to which the species or subspecies of Peromyscus differ in susceptibility to infection by E. multilocularis should be a subject of further investigation.

The abnormal development of the larval cestode in the one muskrat infected experimentally and the failure to find naturally infected muskrats in North Dakota seem to be indicative of differences either in the strain of cestode or in the indigenous subspecies of muskrat. Two muskrats, O. zibethicus spatulatus (Osgood), trapped near Fairbanks, Alaska, were exposed to infection at the same time, with negative results. Muskrats of another subspecies, O. z. zalophus (Hollister), from south central Alaska, were readily infected by the strain of E. multilocularis from St. Lawrence Island (Ohbayashi et al 1971). In the Soviet Union, muskrats have become established after introduction (Rausch 1967) and have been frequently found there to be infected naturally. A rate of about $1 \%$ has been observed in a large series examined in Kazakhstan (Boev et al. 1970). Vogel (1957, p. 410) infected muskrats experimentally, using the European strain of E. multilocularis. Natural infections in muskrats have not been reported in North America.

We could not draw clear conclusions from our findings in the small numbers of rodents of other species that we exposed. Lemmings, Lemmus spp., were not readily infected by the North Dakota strain; in animals of two species infected by the St. Lawrence Island strain, the larvae developed normally and produced many protoscolices. Thirteen-lined ground squirrels, Citellus tridecemlineatus (Mitchill), trapped in North Dakota, also could be infected by the latter strain, although calcareous corpuscles were few and protoscolices were produced in small numbers. All attempts to infect narrow-skulled voles, Microtus miurus muriei Nelson, with either strain have been unsuccessful.

To determine whether the cestodes in North Dakota exhibit any morphological characteristics by which they can be distinguished at the infraspecific level, specimens of E. multilocularis from various geographic regions were compared 
(Table 1). The cestodes originating in southern Germany were of two isolates: one from man, and one from a naturally infected red fox (see Vogel 1957, p. 410). These we reared respectively in dogs from larvae from a field vole, $M$. pennsylvanicus, and from a red-backed vole, C. rutilus, infected by embryophores provided by Prof. Vogel. The cestodes from Japan, provided by Dr. M. Ohbayashi, were collected by Dr. T. Sakamoto from a naturally infected dog in Hokkaido.

The cestodes in all series exhibited a range of non-significant variation in those morphological characters considered to have taxonomic value. However, the lengths of the rostellar hooks appear to differ significantly from region to region. As was determined by Vogel (1957, p. 426), the strain of E. multilocularis in central Europe has slightly larger rostellar hooks than does that in Alaska (and in North Dakota). The strain from Hokkaido has the largest hooks thus far recorded for E. multilocularis, if the series studied may be considered to be representative. We observed no characteristics in the cestodes from North Dakota by which they could be distinguished morphologically from specimens collected in Alaska.

Thus, except for indications of differences in the ability of the larvae to develop in rodents of various species, the cestode in central North America appears to be indistinguishable from that having an extensive geographic range in the Arctic. Such biological differences in the central North American E. multilocularis may represent adaptive changes that have occurred in response to selective factors in a biocenose of which this cestode has only comparatively recently become a part. The possibility that $E$. multilocularis is indigenous at lower latitudes in North America cannot now be excluded, but because its geographic range is so restricted relative to that of suitable hosts, such a possibility seems unlikely. On the other hand, the recent investigations which suggest that the range of E. multilocularis is widening may reflect a greater interest in making more thorough faunistic surveys.

The known distribution of $E$. multilocularis north of $60^{\circ}$ lat. in North America corresponds well to that of the arctic fox. It does not now include the taiga, where the density of potential hosts is usually less and the prey of wild canids is more diversified (Rausch 1967). However, the helminth fauna of mammals of the taiga is not so well known. Surveys in the coniferous forest to the north of the known endemic region in southcentral Canada, especially in Manitoba, may determine whether the range of this cestode is continuous to the zone of tundra west of Hudson Bay, where an infected arctic fox has been recorded as far south as Eskimo Point (Choquette et al. 1962). If the range of the cestode is expanding southward and eastward in the central United States, the rate of its dispersal could be determined by periodic surveys of foxes in the contiguous areas. An expanding range would seem to suggest a comparatively recent introduction of the cestode, either by man or by natural extension from the north.

\section{Acknowledgments}

The series of foxes from northern North Dakota was collected by Messrs. T. Hendrickson, C. Grondahl, G. Strandemo, L. Oldenburg, J. Samuelson, and D. Mitchell, North Dakota Game and Fish Department, Bismarck. At the Arctic Health Research Center, Mr. F. M. Seesee assisted in the laboratory, as did Mrs. V. R. Rausch, who also prepared the figures. The identity of some of the mammals was confirmed by Dr. J. K. Jones, Jr., Museum of Natural History, University of Kansas, Lawrence. Some of the helminths were identified by Dr. A. G. Chabaud and his colleagues, Laboratoire de Zoologie (Vers), Muséum National d'Histoire Naturelle, Paris, and by Dr. G. Dubois, Corcelles, Switzerland. We express our sincere thanks for these essential contributions.

Boev, S. N., V. I. Bondareva, Z. Kh. Tazieva, and I. B. SoKoLova. 1970. Znachenie razlichnykh zhivotnykh v rasprostranenii al'veokokkoza $\mathrm{v}$ Kazakhstane. In Voprosy prirodnoi ochagovosti boleznei. Vol. 3. Nauka, Alma-Ata. pp. 71-78.

CARNEY, W. P., and P. D. LeIBY. 1968. Echinococcus multilocularis in Peromyscus maniculatus and Vulpes vulpes from Minnesota. J. Parasitol. 54: 714.

Chopuette, L. P. E., A. H. Macpherson, and J. G. CousINEAU. 1962. Note on the occurrence of Echinococcus multilocularis Leuckart, 1863 in the arctic fox in Canada. Can. J. Zool. 40: 1167.

FAY, F. H. 1970. Development of larval Echinococcus multilocularis Leuckart in relation to maturation of the intermediate host. J. Parasitol. 56 (Sect. II, Pt. 1): 97-98.

FAY, F. H., and R. L. Rausch. 1966. The seasonal cycle of abundance of Echinococcus multilocularis in naturally 
infected arctic foxes. Proc. Int. Congr. Parasitol. 1st, 2: 765-766.

HaLI, E. R., and K. R. KeLSON. 1959. The mammals of North America. Vol. 2. Ronald Press, New York.

HNATIuK, J. M. 1966. First occurrence of Echinococcus multilocularis Leuckart, 1863 in Microtus pennsylvanicus in Saskatchewan. Can. J. Zool. 44: 493.

Holmes, J. C., J. L. MAhrT, and W. M. Samuel. 1971. The occurrence of Echinococcus multilocularis Leuckart, 1863 in Alberta. Can. J. Zool. 49: 575-576.

KozLov, D. P. 1961. K obnaruzheniiu ekhinokokkov i al'veokokkov u zhivotnykh semeistva Canidae Khabarovskogo Kraia i Kamachatki. Tr. Gel'mintol. Lab. 11: $122-125$.

KuRASHVILI, B. E. 1966. Alveolar echinococcosis in Georgia (USSR). Proc. Int. Congr. Parasitol. 1st, 2: 747-750.

LEE, C-F. 1969. Larval Echinococcus multilocularis Leuckart, 1863 in the southern interlake area in Manitoba. Can. J. Zool. 47: 733-734.

LEIBY, P. D. 1965. Cestode in North Dakota: Echinococcus in field mice. Science, 150: 763 .

LeiBY, P. D., W. P. CARNEY, and C.E. Woods. 1970. Studies on sylvatic echinococcosis. III. Host occurrence and geographic distribution of Echinococcus multilocularis in the north central United States. J. Parasitol. 56: $1141-1150$.

LeiBY, P. D., G. Lubinsky, and W. Galaugher. 1969. Studies on sylvatic echinococcosis. II. The occurrence of Echinococcus multilocularis Leuck. 1863 in Manitoba. Can. J. Zool. 47: 135-138.

LeIBY, P. D., and M. P. NICKEL. 1968. Studies on sylvatic echinococcosis. I. Ground beetle transmission of Echinococcus multilocularis Leuckart, 1863, to deer mice, Peromyscus maniculatus (Wagner). J. Parasitol. 54: $536-537$.
LeIBY, P. D., and O. W. Olsen. 1964. The cestode Echinococcus multilocularis in foxes in North Dakota. Science, 145: 1066.

MENDHEIM, H. 1953. Ein "gefährlicher" Fuchs. Die Pirsch (München.). 5: 639-640.

Ohbayashi, M., R. L. Rausch, and F. H. Fay. 1971. On the ecology and distribution of Echinococcus spp. (Cestoda: Taeniidae), and characteristics of their development in the intermediate host. II. Comparative studies on the development of larval $E$. multilocularis Leuckart, 1863, in the intermediate host. Jap. J. Vet. Res. Suppl. 3. 19: 1-53.

RaUSCH, R. L. 1967. On the ecology and distribution of Echinococcus spp. (Cestoda: Taeniidae), and characteristics of their development in the intermediate host. Ann. Parasitol. Hum. Comp. 42: 19-63.

RausCH, R. L., and E. L. SCHILlER. 1956. Studies on the helminth fauna of Alaska. XXV. The ecology and public health significance of Echinococcus sibiricensis Rausch \& Schiller, 1954, on St. Lawrence Island. Parasitology, 46: 395-419.

RicharDS, S. H and R. L. HINE, 1953. Wisconsin fox populations. Wis. Cons. Dept. Tech. Wildlife Bull. 6.

ScotT, T. G. 1947. Comparative analysis of red fox feeding trends on two central Iowa areas. Iowa Agr. Exp. Sta. Res. Bull. 353 (Ames). pp. 427-487.

ScotT, T. G., and W. D. KLimstra. 1955. Red foxes and a declining prey population. Southern rllinois Univ., Monogr. Ser. 1. Carbondale.

VOGEL, H. 1957. Über den Echinococcus multilocularis Süddeutschlands. I. Das Bandwurmstadium von Stämmen menschlicher und tierischer Herkunft. $Z$. Tropenmed. Parasitol. 8: 404454.

WOBESER, G. 1971. The occurrence of Echinococcus multilocularis (Leuckart, 1863) in cats near Saskatoon, Saskatchewan. Can. Vet. J. 12: 65-68. 